\title{
Philosophical ideas of Roger Williams in the treatise "A Key into the Language of America"
}

\author{
Yaroslav Sobolievskyi \\ Ph.D., Assistant Professor, Taras Shevchenko National University of Kyiv \\ (Kyiv, Ukraine) \\ E-mail: yasobolevsky@gmail.com \\ https://orcid.org/0000-0001-8251-2744
}

\begin{abstract}
Philosophical views of the American thinker Roger Williams on the nature of man, his rights and obligations are described in the article. Thinker's philosophical views were determined by a number of strong political ideas, in particular - secularism; religious nature, namely, tolerance and Baptism; and humanistic, namely abolitionism. Particular attention is paid to the relationship between settlers and indigenous people on language issues. He lived and worked in the colony of Rhode Island, founded by him in 1636, today the official name is the State of Rhode Island and the Providence Plantation. History shows that after he was expelled from the colony of the Massachusetts Bay due to the conflict of religious views, Roger Williams settled at Narragansett Bay, calling this place Providence. This colony became a haven for many pilgrims from religious persecution. The Puritans treated the indigenous people extremely negatively, the Quakers differed with their peace-loving views, and the Catholics carried the word of God. During the preaching of Christianity among the Indians, the Jesuits, unlike the Puritans, did not force the Indians to wear European clothing and used methods that emphasized respect for the traditions of the culture of the indigenous people. In 1643, Roger Williams wrote the book "A Key into the Language of America" (the full name is "A help to the Language of the Natives in that part of America called New England"). He described the language of the $17^{\text {th }}$ century Indians, namely Algonquian language. This book was the first study of the language of the Indians, but in addition to the language itself, the thinker analyzed many philosophical ideas. The philosophical ideas of the treatise are explored in this article.

Keywords: American philosophy; Native American culture; Philosophy of language; Philosophical translation
\end{abstract}

Received: February 15, 2019; accepted: March 4, 2019

Future Human Image, Volume 11, 2019: 98-103.

https://doi.org/10.29202/fhi/11/11

The personality of Roger Williams is thoroughly studied; he was a man who was ahead of his time. At different times his biography and ideas were studied by William Gammell, Zachariah Atwell Mudge, Clifton E. Olmstead, Romeo Elton, who described in detail the events in the life of the philosopher. A detailed memoir was compiled by James D. Knowles. The ideas of the thinker about the nature of man and religion, his philosophical views revealed Vernon Louis Parrington, Herbert Wallace Schneider, Nikita Pokrovsky and others. In the Ukrainian history

(C) Sobolievskyi, Yaroslav, 2019 
of philosophy, one of the studies of the philosophy of Roger Williams was carried out in the article Philosophy of the American thinker Roger Williams: Secularism and Religious Tolerance, in 2017 [Sobolevsky, 2017]. This study emphasizes the philosophical nature of the thinker's views. In 2014, American scientists at Brown University deciphered previously unknown essays by one of New England's most famous and respected thinkers, Roger Williams (1603-1683). Researchers Linford D. Fisher, J. Stanley Lemons and Lucas Mason-Brown found evidence in the texts of the theologian about the forced baptism of the indigenous people of North America. The idea of respecting all Christian denominations and all religions of the world is typical of the views of Roger Williams, who not only theoretically but also in practice tried to demonstrate the cultural and historical necessity of these views. The research methodology is determined by the work of the science department and is described in the monograph Methodological issues of Ukrainian Philosophical Education and Science Modernization [Rudenko, 2017]. Education Roger Williams received in one of the oldest prestigious male schools Charterhouse, as well as at Pembroke College, where he studied Latin, Hebrew, Greek and French. He was personally acquainted with the English poet, politician and thinker of John Milton (1608-1674). Knowledge of languages and personal acquaintances with outstanding personalities of his time formed the philosopher's worldview. He took holy orders in the Anglican Church, but was interested in the basics of Puritanism; this interest did not contribute to his church career:

"Into the controversy which then divided the English church, he had undoubtedly thrown himself with all the energy of his ardent and sanguine temperament. He had thoroughly studied the principles at issue between the two parties, and, with no wavering faith, had embraced the tenets of the persecuted Puritans, who then constituted the most pious portion of the established church. He thus became the associate and friend of Cotton and Hooker and seems to have had occasional intercourse with Vane and Cromwell" [Gammell, 1854: 9].

Despite the fact that in the $17^{\text {th }}$ century, the concept of philosophy essentially differed from how we understand it today, it can be argued that Roger Williams possessed a philosophical turn of mind. In an era when philosophy retained the hallmarks of scholastic doctrine, when new thinking had not yet formed (meaning the development of empiricism and rationalism), in order to be called a philosopher, one had to have an inquisitive mind. In the $17^{\text {th }}$ century, American philosophy was represented by a small number of religious propaganda, social and political ideas, and a small number of printed texts in America. Philosophical thinkers such as John Winthrop, John Cotton and Roger Williams had an English education. At this time, English philosophy was the union of Platonism, the philosophy of Peter Ramus, the scholastic teachings of Aurelius Augustine. Reading ancient texts and knowledge of languages meant being a philosopher. Romeo Elton, an explorer of the life and views of Roger Williams, in his book Life of Roger Williams: The Earliest Legislator and True Champion for a Full and Absolute Liberty of Conscience, 1852, quoted Governor John Winthrop, who spoke on the Roger Williams: "It was the Lyon, Captain William Pierce. Among the passengers was a young minister, godly and zealous, having precious gifts, whose mind was of a philosophic cast, and whose opinions were marked by a strong individuality. This minister was Roger Williams" [Elton, 1853: 14].

It is known that Roger Williams sought to create a state in which problems would be solved by a majority vote, such a majority that would regulate only civil things. The state 
should regulate social relations, and personal beliefs should remain for the consideration of each person. So Roger Williams forms the main issues of his philosophy: firstly, religious and political separatism, secondly, secularism, thirdly, freedom of religion. His utopia was the realization of the garden of the church separated from the wilderness of the world. The foreign relations of the colony with the indigenous people were formed with difficulties. Roger Williams has formed strong friendships with the native Indians. These relationships have generated deep trust among the Indian tribes, especially good relations with the Indian tribe Narragansett or Narragansett people. However, friendly relations with the Aborigines led to the fact that Massachusetts, Connecticut and Plymouth began to clash with Rhode Island. Because of this situation, Roger Williams was forced to return to England and ask for autonomy for his city. There, in 1643, he published the book A Key into the Language of America, the idea was to help communicate with the indigenous people of America. This was the first study of the Indian language, in which the author demonstrated a meticulous approach to the translation and comparison of words, phrases and concepts of two languages. A unique feature of this study was that it was not an ordinary dictionary. The author did not just look for correlates but tried to understand the way of thinking of the Indians, to understand their philosophy. $\mathrm{He}$ studied all human activities from the first greeting to the last burial, trying to demonstrate to European people, despite the obvious difference in cultures, similarities between people. The book A Key into the Language of America was published by Gregory Dexter, it immediately became popular, creating a reputation for Roger Williams.

Roger Williams was proud of his knowledge of languages, he was also proud of his ability to master new languages. The philosopher had a plan to write a simple, but at the same time deep, full of meanings, narration. His book is different in size and style, unlike his subsequent books. The philosopher spent a lot of time reflecting on the theoretical meaning of his vocabulary, and on its practical meaning. In fact, his work corresponds to the type of work of a modern anthropologist or philosopher of a language. According to the author: "My soul's desire was to do the natives good, and to that end to have their language, which I afterwards printed ... God was pleased to give me a painful Patient spirit to lodge with them, in their filthy smoke holes (even while I lived at Plymouth and Salem) to gain their tongue" [Knowles, 1834: 52]. This quote from a letter from Roger Williams is described by James Davis Knowles in his book Memoir of Roger Williams: The Founder of the State of Rhode-Island, 1834. The book consists of 32 chapters, in which Roger Williams poured everything he knew about Narragansett. The text is endowed with a certain logic. So, the book begins with greetings and then proceeds to food, entertainment, and sleep. The analysis continues the daily routine. It ends with the analysis of disease, death and burial. It is fair to say that this is as much a study of culture as a language. The author describes his philosophical views in short chapters between vocabulary lists. From the text, we learn about exceptional physical strength, endurance, insensitivity to cold, insensitivity to hunger. Roger Williams deduces these ideas from observations that Indians are not prone to gluttony and drunkenness. If the rest of the pilgrims, all the barbarians seem alike, and they describe them as savages, then Roger Williams will know that there are many different types of aborigines. But what can and should we know about them? About the indigenous peoples, the philosopher believes, we should know how they eat, how they dress, how they care for themselves and how they interact with the natural world around them. Only through culture, it becomes possible to understand the dialogue between civilizations. The whole work, as noted by researcher Ted Widmer, is characterized by a nostalgic tone: "as if the act of "discovering" America had somehow ruined it as well" [Widmer, 2016]. The second 
edition of the treatise was published by the Massachusetts Historical Society in 1794 and 1798 , respectively. About the third edition, it is known that it was published in 1827 by the Rhode Island Historical Society. The following edition was published in Providence by the Narragansett Club in 1866. In 1936, the fifth edition was published on the $300^{\text {th }}$ anniversary of Rhode Island and Providence Plantations. In the preface to the 1936 edition of Howard M. Chapin (1887-1940) wrote: "Most of the literary productions of seventeenth-century New England were religious controversial tracts, so that this scientific study of the customs and languages of the Indians by Roger Williams is a refreshing surprise, a sort of oasis in a desert of theological thoughts and phrases" [Williams, 1936: III]. The task of the book is not only to provide a dictionary but also to conduct a philosophical study. As is known from the text, Roger Williams conducts a four-part study: "First, by what Names they are distinguished. Secondly, Their Original and Descent. Thirdly, their Religion, Manners, Customs, \&c. Fourthly, That great Point of their Conversion" [Williams, 1643: A3]. He argues about two sources of names in the text, the first is given by settlers (for example, Natives, Barbarians, Indians, etc.), the second is actually American, which they give themselves. According to Roger Williams, the indigenous people did not name themselves before the British gave them the name "Indians". They called themselves simply "Men", "Folke", or "People" and asked why they were called "Indians"? And understanding the real reason, they call themselves Indians, in opposition to English. The philosopher does not limit names and tries to study the history of the emergence of names and the history of tribes. Attempts to trace the history of the Indians, Roger Williams makes like a real Puritan thinker. The philosopher takes as a basis the biblical history which describes the history of mankind as the history of one human race from Adam and Noah. In such a situation, he comes to the idea of the impossibility of determining the beginning of the history of the Indians. He compared the story with the river into which the streams flow. And to understand the flow of the river is impossible. Indians believe in God, believe that He created the world, but the presence of more highly developed material culture of the English suggests them that the English God is more powerful. But the thinker also notes that the Indians are surprised that many years ago the British were of the same level of development of material culture as the Indians. Since Roger Williams knew languages, he could compare American language with European languages and thus trace history. He finds similarities between American and Hebrew, Greek. Indians remind him of Jews, especially their relationship with their wives. However, Roger Williams reveals the similarities between the Greeks and the Indians in that they equally name the seven-star constellation - the Bear. This argument is used by anthropologists to prove the ancient mutual influence of civilizations. For Indians, a belief in a person who walked on water, performed miracles, like the Christian Son of God, is characteristic.

Roger Williams calls his book the "Implicite Dialogue" because the dialogue contained in the text is hidden. Since the time of Plato, the dialogue has been a convenient form for philosophical argumentation, and even if it is implicit in this book, its presence confirms the philosophical nature of the book. In the first chapter, Roger Williams explores greetings; he describes the Indians as well as the English, friendly on the one hand and menacing on the other. Obscure persons amongst them have no names. The name has a sacred meaning for them. Names make a lot of sense during a greeting. The Thinker asserts that the Indians' worldview is characterized by hospitality and kindness. In addition to the dictionary and short explanations, Roger Williams also writes philosophical poetry. His poems complement the ideas described in the chapters of the treatise: 
"Boast not proud English, of thy birth \& blood, // Thy brother Indian is by birth as Good. // Of one blood God made Him, and Thee All. // As wise, as faire, as strong, as personall. // By nature wrath's his portio, thine no more store // Till Grace his soule and thine in Christ // re-Make sure thy second birth, else thou shalt see. // Heaven ope to Indians wild, but shut to thee" [Williams, 1643: 53].

The philosopher focuses on the closeness of the indigenous people and nature. In the concept of time, they proceed from the observation of the Sun and the Moon. They have thirteen Months according to the several Moons, and they give to each significant name. As for religion, the philosopher claims that the Indians believe in God, but their supreme God is multiplied by different gods, and secondly, animals are endowed with divine qualities: "They conceive that there are many Gods or divine Powers within the body of a man: In his pulse, his heart, his Lungs, \&c." [Williams, 1643: 127]. Indians have the exact form of a King, Priest and Prophet, as was the case in Israel, in this Holy Land of Canaan. Their kings or governors governing, their priests perform divine services, their wise and old men make solemn speeches. Roger Williams argues that the Indians have wise men who lecture on religion, peace. Indians have a religious conviction not to interfere with any one person, neither Europeans nor anyone in their worship. Indians use the concept of the soul, and Roger Williams tries to derive the etymology of the word. He is not content with just a translation, for example, derived from "Cowwene" to sleep the word "Cowwewonck" - the Soul, because they say, it works and operates when the body sleeps. The soul also has properties: "Michachunck the soule, in a higher notion which is of affinity, with a word signifying a looking glasse, or cleere resemblance, so that it hath its name from a cleere sight or discerning, which indeed seems very well to suit with the nature of it" [Williams, 1643: 130]. After death, their souls are sent to the likeness of the sky, only their ideas about the sky are significantly different. The philosopher also talks about justice and justice, the thinker comes to the idea of the need for the emergence of the state: "The wildest of the sonnes of Men have ever found a necessity, (for preservation of themselves, their Families and Properties) to cast themselves into some Mould or forme of Government" [Williams, 1643: 145]. The philosopher finishes his treatise with reflections on life and death and summing up, he reads a prayer to God. The style of writing and argumentation allow us to conclude about the great work, despite the fact that the author himself understates the importance of the book. This text is very important from a historical and philosophical point of view, as it allows for a new appreciation of the American philosophy of the $17^{\text {th }}$ century.

\section{Conclusions}

The philosophical mindset of Roger Williams is beyond doubt. His education, knowledge of languages, theology and talent of the writer formed the worldview. His ideas were ahead of their time for many years. Roger Williams made an important philosophical conclusion that has outstripped his time: "For the temper of the braine in quick apprehensions and accurate judgements (to say no more) the most high and soveraign God and Creator, hath not made them inferiour to Europeans" [Williams, 1643: 49]. This proves the fact that all people are equal, that all have the same mind and are created with one blood: "Nature knowes no difference between Europe and Americans in blood, birth, bodies, \&c. God having of one blood made all mankind. Acts 17. and all by nature being children of wrath, Ephes. 2" [Williams, 1643: 53]. 
He believed in reason and logic, considered everyone equal and believed in the inalienable human rights to religious freedom and church independence from government. This leads to the conclusion that the ideas of Roger Williams are closer to the American Enlightenment than to Puritanism. The philosophical analysis of the ideas of the thinker allows us to understand the history of early American philosophy.

The fact that attempts of the past to solve the problems of the dialogue of cultures, mutual understanding and tolerance proves that the problems of our time are relevant. Roger Williams proposed unique views for his time on the problem of the dialogue of cultures, studying it, it becomes possible to better understand the problems of our time and develop strategies for solving them in the future. The philosophical views of the past are relevant today and, by studying them, we can apply the results to solve the problems of the future. For the 17th century, Roger Williams was the man who was ahead of his time; he was really the man of the future.

\section{References}

Elton, Romeo. Life of Roger Williams: The Earliest Legislator and True Champion for a Full and Absolute Liberty of Conscience. Providence: G. H. Whitney, 1853.

Gammell, William. Life of Roger Williams the Founder of the State of Rhode Island. Boston: Gould and Lincoln, 1854.

Knowles, James Davis. Memoir of Roger Williams: The Founder of the State of Rhode-Island. Boston: Lincoln, Edmands, 1834.

Rudenko, Sergii, Viacheslav Vilkov, Natalia Yarmolitska, and Yaroslav Sobolievkyi. Methodological issues of Ukrainian Philosophical Education and Science Modernization. Kyiv: Kyiv University Publishing Centre, 2017.

Sobolevsky, Yaroslav. Philosophy of the American thinker of Roger Williams: secularism and religious tolerance. Gileya. Volume 122, 2017: 230-233.

Widmer, Ted. A Key into the Language of America. URL: http://www.findingrogerwilliams. com/essays/an-essay-on-a-key-into-the-language-of-america

Williams, Roger. A Key into the Language of America: or, in help to the Language of the Natives in the part of America, called New-England. London: Printed by Gregory Dexter, 1643.

Williams, Roger. A key into the language of America. $5^{\text {th }}$ ed. Providence: Rhode Island and Providence Plantations Tercentenary Committee, 1936. 